\title{
THE ISSUES OF TERMINOLOGY STANDARDIZATION IN THE FIELD OF MARKETING
}

\author{
Maja Lazovic \\ College of Fine and Applied Arts, Belgrade, Serbia
}

\section{Ljiljana Jovkovic}

Faculty of Business and Law, "Union - Nikola Tesla" University, Belgrade, Serbia

\section{CMESTE}

JEL Category: M31, Z13

\begin{abstract}
The purpose of this paper is to provide insights into the issues of marketing terminology standardization from the translation perspective by contrasting the English and Serbian languages of marketing. Nowadays in the era of globalization processes and all respective communication phenomena, the treatment of the field of marketing is of utmost importance. This particularly refers to the need for prescribing principles, norms, and standards when dealing with translation. The field of marketing has been extremely topical and challenging for a long time. It is the field with the greatest number of internationally recognizable anglicisms among its terms. The Serbian language is no exception with all its specific modes of using anglicisms. The paper encompasses adequate term usage with a special emphasis on the frequent use of anglicisms, their adaptation, and the standardization of terminology. The process of standardization requires the elaboration of definite phases and sequence of steps. The first and probably most essential phase refers to establishing a normative body certified by adequate professional and expert institutions at the national level. The next phase would include determining and defining the terminological principles taking into consideration appropriate contrastive elements at all linguistic levels. A significant precondition that would facilitate efficient standardization is the existence of reliable reference books such as specialized dictionaries, glossaries, manuals, and similar material. The permanent cooperation between language and marketing experts is necessary to ensure a successful outcome of this endeavor. The authors point out the necessity of adopting norms and standardization principles when translating from English into Serbian with special reference to marketing terminology and expressions such as marketing slogans and other specific tools of marketing.
\end{abstract}

Keywords: marketing terminology, Anglicism, terminology standardization, language norms, a specialized dictionary

Address of the corresponding author:

Maja Lazovic

夆=mayalaz8@yahoo.com 


\section{ENGLISH - THE LANGUAGE OF MARKETING}

The English language is the language of marketing due to the following facts: the greatest amount of literature in the field of marketing is written in English; the majority of authors and marketing experts come from Anglo societies such as the USA, the UK, Canada, Australia; English is used for almost all marketing activities worldwide, particularly those pertaining to advertising and promotion regardless of the native language of the particular country; and consequently there is a much greater number of Anglicisms compared to other fields of business economics. The Serbian language is no exception in this respect. Therefore, studying marketing terminology and respective standardization issues primarily assumes dealing with a complex corpus of Anglicisms issues.

The language of marketing and advertising is simple, striking, memorable, effective, amusing and as such suitable to serve this purpose.

The global language of advertising and marketing is English. Advertisers throughout the world use English words, sentences, and even entire texts as an efficient strategy to sell brands and products to consumers. English serves as a "lingua franca" that is understood by people in different countries. The process of globalization and the development of the global market have been accompanied by the development of international marketing and all related activities. These processes preceded Information Technology expansion which brought about a definite domination of the English language as a global or international language.

English is associated with today's dominant cultural values of western civilization; they reflect Anglo-American models of internationalism, modernity, prestige, youth, globalization, cosmopolitism, and other positive stereotypes.

Since English has become the international or global language, it has turned into a "neutral" and "transparent" language, tied to no particular social, political, economic, or religious system, belonging to everyone or no one.

It is necessary to emphasize that the English language is used not only for advertising and marketing of American and British brands but also for promoting all other famous French, German, Scandinavian, Japanese, and other brands.

It is almost impossible to imagine a famous brand coming from any country that is not advertised in English.

Leo Burnett, one of the most famous advertising experts and slogan producers, gives guidelines for the language of advertising: "Make it simple. Make it memorable. Make it inviting to look at. Make it fun to read." (Burnett, 2018)

To serve this purpose, the language of advertising uses plain, clear, concise language elements, simple and catchy vocabulary, short, and effective language structures. The field of advertising and marketing recognized the need for the use of "plain English" long ago. Nowadays Plain English movements of Britain and the USA are advocating the use of uncomplicated clear and simple English in all spheres of life. "Plain English campaigns" continue to grow and they are the outcome of the requirements of modern times. (Crystal, 2010, p. 398)

\section{MARKETING TERMINOLOGY}

Ideally, a term should be transparent, internationally recognizable, consistent, concise, precise, unambiguous, system compatible, nonsynonymous. This paper focuses on the following two features of marketing terms due to their specific validity regarding English - Serbian translation processes: being internationally recognizable and non-polysemous. (Sipka, 1998, p. 28).

Terminological borrowings from English into Serbian in the field of marketing mostly take place as a result of an urgent need to create terms when there are no equivalents in the Serbian language. Anglicisms are therefore used to fill in the gaps. Of course, there are various degrees of justification for the introduction of Anglicisms into Serbian ranging from relatively unjustified to completely justified borrowings. This among other reasons brings about the necessity for terminology standardization activities.

The term marketing itself is an outstanding example of a completely justified Anglicism not only in Serbian but also in other languages worldwide. The same is true for a derived term such as marketing mix. Advertising is an example 
of a relatively justified Anglicism as we already have Serbian words "oglašavanje" and "reklamiranje".

Borrowing from English and using the word in Serbian with or without adapting it appears to be quite easy, convenient, and above all extremely trendy nowadays. The English terms are used not for their real advantage over Serbian ones in terms of being objectively more powerful and more precise in meaning, but because people are more inclined to perceive the foreign words as something special, mystical, extraordinary, complicated. There is a very well-known tendency to sound more sophisticated, more bookish as a reflection of the so-called intellectual elitism and snobbism. Professional prestige connected to the English language is one of the reasons for the introduction of a great number of Anglicisms in marketing terminology. These two different justifications for using Anglicisms in Serbian are mentioned by Tvrtko Prcic (2005, p. 150), who identifies two tendencies:

1. professional reasons mostly motivated by experts' view that only English terms express the meaning clearly and authentically ignoring Serbian.

2. status reasons, mostly motivated by a strong belief that using Anglicisms helps to make a stronger impression on the audience and to appear more elegant, modern, and novel.

The authors of this paper believe that the experts' tendency and need to maintain international recognition of terminology bring about the following major problems:

1. the first problem refers to the derivational capacity of Anglicisms in the process of adaptation into the Serbian language system (orthographic, phonological, morphological, and semantic level). For example, the term marketing concept in translation into Serbian appears either as unchanged or translated as "marketinški koncept" (marketing is used as an adjective) or translated as "koncept marketinga" (marketing is used as a genitive case).

2. the second problem refers to the adaptation of English terms on the semantic level into the Serbian language causing the introduction of semantic neologisms. The typical examples are training, and recruitment of staff translated as "trening zaposlenih" and "regrutovanje zaposlenih". These words are in Serbian traditionally related to sports terminology training and military terminology - recruitment. We do already have precise Serbian words for these expressions: "obuka zaposlenih" and "zapošljavanje kadrova".

3. the third problem refers to a rapid direct borrowing of English terms containing words with several meanings that are phonologically similar but associated with completely different meanings in the Serbian language. The typical example is marketing intelligence translated as "marketing / marketinška inteligencija". The word "inteligencija" in Serbian does not have the meaning of information as in English.

International recognition of terminology is a rational and economical method of creating professional terms and therefore it is not necessary to insist on linguistic purism at all costs. However, it is necessary to insist on establishing norms, principles, and standards concerning the ways of their adoption and translation. This particularly refers to the issue of the adoption of Anglicisms into Serbian and the degree of justification of their introduction into Serbian terminology.

The adaptation of Anglicisms into the Serbian language takes place at four main levels: orthographic, phonological, morphological, and semantic.

Orthographic adaptation could range from:

1. literal rewriting of the original, i.e. zero adaptation such as "public relations" (PR)," remarketing".

2. modified, i.e. simplified rewriting of the original "stejkholderi", "mejling liste".

3. arbitrary transcription of the original "benčmarking", "faktoring", "džoint venčer".

4. calque i.e. that is literal word-for-word or rootfor-root translation of English words such as "marketinška agencija".

There are many examples of adaptation at the phonological level in marketing terminology: "brend", "imidž", "advertajzing", "merčendajzer", merdžer, etc.

Morphological level examples in marketing terminology include among others: "distribucija", "distributer", "kastomizacija", "damping". 
When it concerns the semantic level, which is perhaps the most complex, various semantic changes could occur in the process of adaptation of Anglicisms. Those changes could imply narrowing or extending the meaning the word has in English. Of course, when the meaning remains equivalent to English there is zero semantic adaptation of the term.

"Market" is used in the Serbian language with a narrower meaning: "a retail store". "Dragstor" is another example of a narrower meaning: "a shop working longer hours". Serbian "outlet" means: "shop with reduced prices". The following terms mostly retain the English meaning: cash and carry, outsourcing, brand, design, digital marketing, and many others.

\section{STANDARDIZATION TERMINOLOGY}

Marketing terminology with all its specific features inevitably requires certain standardization procedures at both national and international levels. Special concern should be devoted to contrasting English and Serbian marketing terms. The process of standardization requires the elaboration of definite phases and sequence of steps.

The first and probably most essential phase refers to establishing a normative body certified by adequate professional and expert institutions at the national level. This body should take the form of a committee for marketing terminology standardization and should consist of members representing the following specialists: marketing experts, experts from the academic and professional sphere (university scholars, marketing agencies, marketing companies, corporate marketing managers, language institutes, the national association of translators, the international organization for standards -ISO, etc.).

The primary goal of this body should refer to adopting the norms and standardization principles related to marketing terminology translation issues and implementing methodological standards for terminology and language resources. To achieve this goal, the body should probably first draw up a document provisionally entitled "National Strategy for Terminological Standardization in Marketing".

The next phase would include determining and defining the terminological principles taking into consideration appropriate contrastive elements at all linguistic levels. The main purpose of conducting this phase would be to try to establish order and provide the grounding for a systematic approach in dealing with marketing terminology instead of the present "chaotic" situation. The science of language has not invented so far, a better method than contrastive analysis when trying to introduce norms, principles, and order of things with all its advantages and disadvantages. Therefore, the methodology of contrastive analysis should be applied to the treatment of marketing terminology and its standardization from a translation perspective. This phase of standardization procedures also includes a large corpus of Anglicisms as already discussed in this paper.

The specific feature of marketing terminology is that it contains a special segment of language expressions in addition to the terms themselves. This refers to a special corpus of expressions such as slogans, marketing propositions, and similar marketing communication tools. This corpus is an inevitable component of marketing and as such requires to be standardized similarly as the rest of marketing terminology.

A significant precondition that would increase the efficiency of the standardization process is the existence of reliable reference books such as specialized dictionaries, glossaries, manuals, and similar material.

Speaking of dictionaries and similar reference books, the general situation in Serbia is an absolute lack, or even absence of all contemporary dictionaries including specialized ones (Prcic, 2016). Monolingual, bilingual, and multilingual dictionaries of marketing are no exception. Therefore, lexicographic work which would result in the creation of a terminological English Serbian and Serbian English dictionary of marketing would be of the utmost importance in resolving the problems of standardization.

Certain basic principles should be prescribed for future authors of such a dictionary. These principles should refer to the following issues: 
a. The major sources for collecting terminological entries should include monolingual specialized English dictionaries of marketing, prepared by well-known recognized publishing houses, the existing English Serbian and Serbian English dictionaries, English and Serbian textbooks written by reputable professors of marketing, various publications in the field of marketing such as manuals, glossaries, journals, digital material, web corpus, and other media sources. Besides translation equivalent, the entries should include cross-references, synonyms, and examples. Most terms require a concise definition. Definitions should be compulsory in each terminological dictionary. This is the most demanding and delicate task in compiling such dictionaries considering the above-mentioned principles for the application of Anglicisms.

b. The team of dictionary authors should consist of linguists, translators, academic and professional marketing experts who are not only proficient in English and but also computer experts.

c. The most practical, efficient approach would be provided by applying digital i.e. electronic, "e-lexicography". The electronic form of such a dictionary has many advantages over other traditional publications. The lexicographic work is much easier, less complicated, and faster. It is less costly to prepare and to use such a dictionary. A special advantage refers to great possibilities for on-going editing, supplementing, changing, revising, and similar activities of crucial importance for the lexicographic endeavor. Of course, an electronic dictionary does not exclude traditional printed options.

Finally, to come out with such a dictionary should not take too much time striving for perfect reference material. What we need is a solid, not overly pretentious, easy to use, edition reliable to begin with, having in mind the wise words of the father of English lexicography Samuel Johnson who said a long time ago: "Dictionaries are like watches, the worst is better than none and the best cannot be expected to go quite true". (Johnson, 1784)

\section{CONCLUDING REMARKS}

The characteristics of the language of marketing could be summarized as follows:

1. The English language is the language of marketing; It is the global internationally recognizable English language of marketing and advertising and as such is simple, striking, memorable, effective and above all plain, belonging to everyone and no one, reflecting today's dominant cultural values of western civilization: Anglo-American models of internationalism, modernity, prestige, youth, globalization, cosmopolitism and other positive stereotypes;

2. Consequently, the language of marketing and marketing terminology uses the greatest number of Anglicisms compared to other fields of business economics and the Serbian language is no exception.

- Therefore, studying marketing terminology and respective standardization issues primarily assumes dealing with a complex corpus of Anglicisms issues.

- There are various degrees of justification for the introduction of Anglicisms into Serbian ranging from relatively unjustified to completely justified borrowings.

- This among other reasons brings about the necessity for terminology standardization activities.

3. The treatment of the marketing terminology standardization from a translation perspective (English Serbian and vice versa) requires a series of steps to be taken:

- Establishing a normative body certified by adequate professional and expert institutions at the national level consisting of language and marketing specialists and experts from the academic and professional sphere.

- This body should first draw up a document provisionally entitled "National Strategy for Terminological Standardization in Marketing".

- Among the fundamental steps, special attention should be devoted to determining and defining the terminological principles and language norms applying the methodology of contrastive analysis at all linguistic levels. 
- The final step refers to creating a Because of the complexity and ever-changing reference book in the form of a lexicographic language corpus concerned, the specialized terminological bilingual authors suggest an electronic version of such a English Serbian dictionary of marketing. dictionary.

\section{WORKS CITED}

Burnett, L. (2018, 05 16). Top 25 Advertising Quotes By Leo Burnett. Retrieved from AKsharit: https://aksharit.org/2018/05/16/top-25-advertising-quotes-by-leo-burnett/

Crystal, D. (2010). The Cambridge Encyclopedia of Language. Cambridge: CUP.

Johnson, S. (1784, 08 21). Letter to Fransesco Sastres. Retrieved from Quotes on Dictionaries: https://www.samueljohnson.com/dictiona.html

Prcic, T. (2005). Engleski u srpskom. Novi Sad: Zmaj.

Prcic, T. (2016). Kakav nam opšti rečnik srpskog jezika najviše treba. Zbornik naučnih radova Leksikologija i leksikografija u svetlu savremenih pristupa, 87-116.

Sipka, D. (1998). Osnovi leksikologije i srodnih disciplina. Novi Sad: Matica Srpska.

Received for publication: $\quad 22.01 .2020$

Revision received: $\quad 31.03 .2020$

Accepted for publication: $\quad 01.07 .2020$

\section{How to cite this article?}

Style - APA Sixth Edition:

Lazovic, M., \& Jovkovic, L. (2020, July 15). The issues of terminology standardization in the field of marketing. (Z. Cekerevac, Ed.) MEST Journal, 8(2), 114-119. doi:10.12709/mest.08.08.02.12

Style - Chicago Sixteenth Edition:

Lazovic, Maja, and Ljiljana Jovkovic. 2020. "The issues of terminology standardization in the field of marketing." Edited by Zoran Cekerevac. MEST Journal (MESTE) 8 (2): 114-119. doi:10.12709/mest.08.08.02.12.

Style - GOST Name Sort:

Lazovic Maja and Jovkovic Ljiljana The issues of terminology standardization in the field of marketing [Journal] // MEST Journal / ed. Cekerevac Zoran. - Belgrade - Toronto : MESTE, July 15, 2020. - 2 : Vol. 8. - pp. 114-119.

Style - Harvard Anglia:

Lazovic, M. \& Jovkovic, L., 2020. The issues of terminology standardization in the field of marketing. MEST Journal, 15 July, 8(2), pp. 114-119.

Style - ISO 690 Numerical Reference:

The issues of terminology standardization in the field of marketing. Lazovic, Maja and Jovkovic, Ljiljana. [ed.] Zoran Cekerevac. 2, Belgrade - Toronto : MESTE, July 15, 2020, MEST Journal, Vol. 8, pp. 114-119. 